\title{
The role of coastal accumulations of the Spirogyra spp. filamentous algae as a methane source in the littoral zone of Lake Baikal
}

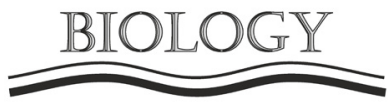

www.limnolfwbiol.com

\author{
Bukin S.V. ${ }^{1 *}$, Pavlova O.N. ${ }^{1}$, Kalmychkov G.V. ${ }^{2}$, Ivanov V.G. ${ }^{1}$, Sakirko M.V. ${ }^{1}$, \\ Timoshkin O.A. ${ }^{1}$ \\ ${ }^{1}$ Limnological Institute, Siberian Branch of the Russian Academy of Sciences, Ulan-Batorskaya Str., 3, Irkutsk, 664033, Russia \\ ${ }^{2}$ Vinogradov Institute of Geochemistry, Siberian Branch of the Russian Academy of Sciences, Favorsky Str., 1A, Irkutsk, 664033, \\ Russia
}

\begin{abstract}
Excessive input of nutrients is one of the main causes of large-scale blooms of benthic algae in the coastal zone of water bodies, which has significant deleterious effects on biodiversity, abundance, and biomass of benthic littoral community. The decay of massive coastal accumulations of benthic algae can lead to secondary pollution in the littoral zone as well as be a source of methane, the second most important greenhouse gas. We experimentally studied methane production during decomposition by native microbial community of algal biomass of the Spirogyra spp. coastal accumulation from Lake Baikal. Methanogenesis was recorded both in the absence of additionally introduced biogenic elements and under elevated concentrations of phosphates. Under mesophilic temperature conditions $\left(24^{\circ} \mathrm{C}\right.$ and $37^{\circ} \mathrm{C}$ ), the methane yield was $0.005-0.006 \mathrm{~m}^{3} \mathrm{CH}_{4} \mathrm{~kg}^{-1}$ of the algal dry weight. Among the methanogens, we detected the members of the genera Methanobacterium and Methanosphaerula
\end{abstract}

Keywords: methane, Spirogyra, filamentous algae, Lake Baikal, anaerobic decomposition

\section{Introduction}

Algae are one of the main sources of organic carbon in aquatic ecosystems (Wetzel, 1995; Matveev and Robson, 2014). Currently, the frequency and extent of algal blooms in freshwater and marine water bodies are increasing throughout the world (Auer et al., 2010; Gubelit and Vanshtein, 2011; Schneider et al., 2014; Huisman et al., 2018). In many cases, the rapid increase in the number and biomass of algae is associated with the elevated concentrations of nutrients (nitrogen and/ or phosphorus) in the environment, one of the possible causes of which is the anthropogenic impact (Smith et al., 2006; Depew et al., 2011; Jenny et al., 2016). In addition to the possible suppressing effect of blooms on the coastal benthic communities, the destruction of coastal accumulations of algae can lead to the formation of hypoxia zones inside them, into which a large amount of labile organic carbon enters (Hecky and Hesslein, 1995; Ask et al., 2009; Hale et al., 2016). A rise in the concentrations of organic matter in anoxic zones intensifies the activity of anaerobic processes, including the biogenic formation of methane with its subsequent emission into the atmosphere (Schwarz et al., 2008; West et al., 2012; Liang et al., 2015). In this regard, the composition and functioning of a microbial community involved in algal detritus turnover is a relevant issue of modern research (Morrison et al., 2017; Mikhailov et al., 2019). Moreover, benthic algae are regarded as a promising tool for the wastewater treatment, and microbial communities decomposing their biomass - as biogas producers (Montingelli et al., 2015; Milledge et al., 2019).

To date, much attention is paid to negative environmental changes in the coastal zone of Lake Baikal, one of which is the massive development of green filamentous algae of the genus Spirogyra (Kravtsova et al., 2014; Timoshkin et al., 2016; 2018; Potemkina et al., 2018). From 2007 to 2012, there were the first outbreaks of the massive development of Spirogyra spp. recorded in Listvennichny Bay (Kravtsova et al., 2012; 2014) and Bolshiye Koty Bay (Timoshkin et al., 2015). The results of recent studies have indicated the presence of these algae in the littoral zones of all basins of the lake (Volkova et al., 2018; Kravtsova et al., 2020).

In the autumn, the wet biomass of Spirogyra spp. can exceed $300 \mathrm{~g} \mathrm{~m}^{-2}$ in the coastal zone of some areas, and its coastal accumulations can reach $90 \mathrm{~kg}$ $\mathrm{m}^{-2}$ (Timoshkin et al., 2015; 2016). It is very likely that not only aerobic but also anaerobic microorganisms are involved in the decomposition of such large accumulations of detritus. The example of Lake 
Michigan revealed a high abundance of anaerobic heterotrophic and sulfate-reducing bacteria (Olapade et al., 2006; Chun et al., 2017) as well as the presence of methanogenic archaea (Byappanahalli et al., 2019) in the microbial communities of coastal mats consisting of filamentous algae of the genus Cladophora. When the algal biomass enters bottom sediments and anaerobic layers of the water column of freshwater lakes, there is a significant increase in the number of methanogenic archaea and the rates of methane generation (West et al., 2012; Liang et al., 2015; Morrison et al., 2017). However, an increase in the rates of methane oxidation in the water column compensates an increase in the methane emission from bottom sediments, whereas methane from coastal mats can directly enter the atmosphere. At the same time, in the coastal accumulations of detritus, the high concentration of nutrients and competition for common substrates with sulfate- and nitrate-reducing microorganisms can suppress the development of methanogens (Liu and Whitman, 2008). In this regard, the aim of this study was to detect methane producers in microbial communities of the coastal accumulations of algae, which are mainly represented by the Spirogyra spp. filaments, as well as to assess their productiveness during the destruction of algal biomass at elevated concentrations of nutrients under mesophilic temperature conditions that are optimal for methanogenesis.

\section{Material and methods 2.1 Sampling site}

The algal biomass was sampled in September 2014 from the coastal mats in Senogda Bay (Northern Baikal) during the expeditions onboard the research vessel "Akademik V.A. Koptyug".

\subsection{Cultivation}

To obtain enrichment cultures of microbial communities, $1 \mathrm{~g}$ of wet detritus mainly consisting of the Spirogyra spp. filaments was placed in $120 \mathrm{~m}$ vials that contained $40 \mathrm{ml}$ of a liquid medium with the following compositions:

1. Sterile Baikal water;

2. Sterile Baikal water $+\mathrm{NH}_{4} \mathrm{Cl}\left(5 \mathrm{mg} \mathrm{L}^{-1}\right)$;

3. Sterile Baikal water $+\mathrm{NaNO}_{3}\left(50 \mathrm{mg} \mathrm{L}^{-1}\right)$;

4. Sterile Baikal water $+\mathrm{KH}_{2} \mathrm{PO}_{4}\left(13 \mathrm{mg} \mathrm{L}^{-1}\right)$;

5. Sterile Baikal water $+\mathrm{NaNO}_{3}\left(50 \mathrm{mg} \mathrm{L} \mathrm{L}^{-1}\right)+$ $\mathrm{KH}_{2} \mathrm{PO}_{4}\left(13 \mathrm{mg} \mathrm{L}^{-1}\right)$;

6. Sterile Baikal water $+\mathrm{NaNO}_{3}\left(50 \mathrm{mg} \mathrm{L}^{-1}\right)+$ $\mathrm{KH}_{2} \mathrm{PO}_{4}\left(13 \mathrm{mg} \mathrm{L}^{-1}\right)+\mathrm{NH}_{4} \mathrm{Cl}\left(5 \mathrm{mg} \mathrm{L}^{-1}\right)$;

7. Pfennig's mineral medium with the following composition: $\left(\mathrm{g} \mathrm{L}^{-1}\right)$ : $\mathrm{NaCl}-0.3 ; \mathrm{NH}_{4} \mathrm{Cl}-0.33$; $\mathrm{KH}_{2} \mathrm{PO}_{4}-0.33 ; \mathrm{MgCl}_{2} \cdot 6 \mathrm{H}_{2} \mathrm{O}-0.33 ; \mathrm{CaCl}_{2} \cdot 2 \mathrm{H}_{2} \mathrm{O}-$ $0.33 ; \mathrm{NaHCO}_{3}-1$; resaruzin $-1 ; \mathrm{Na}_{2} \mathrm{~S} \cdot 9 \mathrm{H}_{2} \mathrm{O}-0.6$ (Kuznetsov and Dubinina, 1989);
8. Pfennig's mineral medium and the $\mathrm{H}_{2}+\mathrm{CO}_{2}$ atmosphere (anaerobic positive control);

9. Sterile Baikal water + air atmosphere (aerobic negative control);

10. Sterile Baikal water and autoclaved biomass (anaerobic negative control).

The vials were sealed with rubber stoppers; anaerobic media were purged with oxygen-free nitrogen or the $\mathrm{H}_{2} / \mathrm{CO}_{2}$ mixture $\left(105 \mathrm{mmol} \mathrm{L}^{-1} / 35 \mathrm{mmol} \mathrm{L}^{-1}\right)$ and placed in thermostats at 24 and $37^{\circ} \mathrm{C}$ for 90 days. Prior to weighing the wet biomass, excess water was removed with filter paper. To determine the dry weight (DW), algae were dried in a thermostat at $105^{\circ} \mathrm{C}$ for 24 hours, then cooled to room temperature and weighed.

\subsection{Gas chromatography}

The concentrations of hydrocarbon gases in the experimental vails were determined by headspace technique (Bolshakov and Egorov, 1987). Methane in gaseous phase was analysed on an EKHO-PID chromatograph (Russia) (flame ionization detector, $2 \mathrm{~m}$ packed column with an inner diameter of $2 \mathrm{~mm}$; the Porapak Q sorbent, isothermal mode, column temperature $100^{\circ} \mathrm{C}$, injector temperature $100^{\circ} \mathrm{C}$ and detector temperature $150^{\circ} \mathrm{C}$ ). The gas volume for analysis was $0.05 \mathrm{ml}$. The methane concentrations in the atmosphere of vials with enrichment cultures were measured one hour later after the addition of biomass and then on the $30^{\text {th }}$ and $90^{\text {th }}$ days.

\subsection{Molecular biological detection methods}

Preparations for fluorescence in situ hybridization (FISH) and calculation of the total bacterial count were fixed according to the previously proposed technique (Glöckner et al., 1999). To assess the diversity and number of methanogenic microorganisms, hybridization was carried out with the EURY498 oligonucleotide probe (5'- CTT GCC CRG CCC TT, Burggraf et al., 1994) specific to the archaeal DNA region of the phylum Euryarchaeota, to which most of the known methanogens belong. The NON probe (5'ACT CCT ACG GGA GGC AGC, Wallner et al., 1993), which has no complementarity with the 16S rRNA gene regions, served as a negative control. The probes were labelled with a CY3 fluorescent dye (Syntol, Russia). After washing from the probe, preparations were stained with 4',6-diamidino-2-phenylindole (DAPI). Microscopy was carried out on an Axio Imager M1 epifluorescent microscope (ZEISS, Germany).

Preparations of total DNA from the biomass of enrichment cultures of microorganisms were extracted on the $90^{\text {th }}$ day according to the modified enzymatic lysis method followed by phenol-chloroform extraction (Sambrook et al., 1989).

Archaeal 16S rRNA gene fragments were amplified using the Arch21F (5'- TCC CGG TTG ATC CYG CCR G)/Arch915R (5'- GTG CTC CCC CGC CAA TTC CT) primer pairs. 
The obtained gene fragments were cloned and transformed using the pGEM-T Easy Vector Systems reagent kit (Promega, USA) according to the manufacturer's protocol.

Sanger sequencing using the BigDye Terminator Kit v. 3.1 (Applied Biosystems) and analysis of its products were carried out on an ABI $3130 \times 1$ genetic analyser at SB RAS Genomics Core Facility (Novosibirsk).

Primary processing and phylogenetic analysis of the obtained nucleotide sequences were carried out in the MEGA 7.0.26 software package (Kumar et al., 2016) using the neighbour-joining clustering method and Kimura's two parameters algorithm to construct phylogenetic trees. The statistical significance of branching was assessed using a bootstrap analysis of 1000 alternative trees. Homologous sequences were searched in the NCBI database using the BLAST algorithm (www.ncbi.nlm.nih.gov/blast). The obtained 16S rRNA gene fragments were deposited in the NCBI database under accession numbers KJ736828KJ736834.

\section{Results}

During the cultivation, there were visual changes reflected in the partial destruction of the algal biomass for all types of the media both at $24^{\circ} \mathrm{C}$ and $37^{\circ} \mathrm{C}$ (Fig. 1 ). By the end of the experiment, enrichment cultures exposed at higher temperature showed lower turbidity and no suspension.

Total microbial count (TMC) on the $30^{\text {th }}$ day varied between $0.4-8.8 \cdot 10^{7}$ cells $\mathrm{ml}^{-1}$ and $0.5-9.1$. $10^{7}$ cells $\mathrm{ml}^{-1}$ at $24^{\circ} \mathrm{C}$ and $37^{\circ} \mathrm{C}$, respectively (Fig. 2). We recorded the maximum values under aerobic conditions, and the minimum ones - on a medium added by ammoniacal nitrogen. The media with nitrate and phosphate had the greatest number of microorganisms in anaerobic cultures $\left(3.1-3.5 \cdot 10^{7}\right.$ cells $\left.\mathrm{ml}^{-1}\right)$, whereas the addition of ammonium salt to them resulted in lower TMC values $\left(1.2-1.9 \cdot 10^{7}\right.$ cells $\left.\mathrm{ml}^{-1}\right)$.

Based on the FISH results, we detected archaea of the phylum Euryarchaeota in anaerobic communities that were cultured at two temperatures on a medium without additional salts $\left(0.1-0.2 \cdot 10^{7}\right.$ cells $\mathrm{ml}^{-1}, 13-25 \%$ of TMC) and on a medium with phosphates (0.1-0.4 $\cdot 10^{7}$ cells $\mathrm{ml}^{-1}, 4.6-23.6 \%$ of TMC) (Fig. 2). In positive controls with additionally introduced substrates of methanogenesis (Pfennig's mineral medium with $\mathrm{H}_{2}$ / $\mathrm{CO}_{2}$ ), the proportion of methanogens was between 36 and $40 \%$ of TMC $\left(0.4-0.7 \cdot 10^{7}\right.$ cells $\left.\mathrm{ml}^{-1}\right)$.

In the next 60 days of exposition, the number of microorganisms increased by $21-431 \%$ at $24^{\circ} \mathrm{C}$, depending on the type of the media, whereas at $37^{\circ} \mathrm{C}$, it increased by $6-156 \%$, and in control samples (aerobic medium, Pfennig's mineral medium with $\mathrm{H}_{2}$ / $\mathrm{CO}_{2}$ ), the TMC values decreased. At the same time, the distribution nature of the maximum and minimum TMC values between media did not change (Fig. 2). In comparison with the $30^{\text {th }}$ day, the proportion of microorganisms of the phylum Euryarchaeota on a medium without additionally introduced nutrients increased from $13-25 \%$ to $39 \%$ of TMC, whereas a medium with phosphates did not show methanogens at $24^{\circ} \mathrm{C}$, and at $37^{\circ} \mathrm{C}$, their share decreased from $23.6 \%$ to $9.1 \%$ of TMC (Fig. 2). In the positive control, the number of methanogenic archaea remained at the same level (36-40\% of TMC).

The results of measuring the methane concentrations were mainly correlated with the hybridization data. On the Pfennig's medium with the $\mathrm{H}_{2} / \mathrm{CO}_{2}$ atmosphere, 3.66-4.47 $\mathrm{mmol} \mathrm{L}^{-1} \mathrm{CH}_{4}$ were formed for 90 days, which suggests, regardless of methane oxidation and use of substrates resulted from the biomass destruction, the $14-17 \%$ consumption of the introduced $\mathrm{H}_{2}$ for methane generation. On anaerobic media without nutrients and with phosphates, where the algal biomass was the only carbon source, 0.22 $1.05 \mathrm{mmol} \mathrm{L}^{-1} \mathrm{CH}_{4}$ were generated (Fig. 3). With the measured ratio of wet and dry biomass of 1/0.176 \pm 0.005 , the methanogenesis productivity on these media varied within the range of $0.005-0.006 \mathrm{~m}^{3} \mathrm{CH}_{4} \mathrm{~kg}^{-1}$ of the algal DW.

Analysis of the diversity of the archaeal 16S rRNA genes in enrichment culture without nutrients (at $24^{\circ} \mathrm{C}$ and $37^{\circ} \mathrm{C}$ ) revealed the presence of microorganisms in them, which were phylogenetically

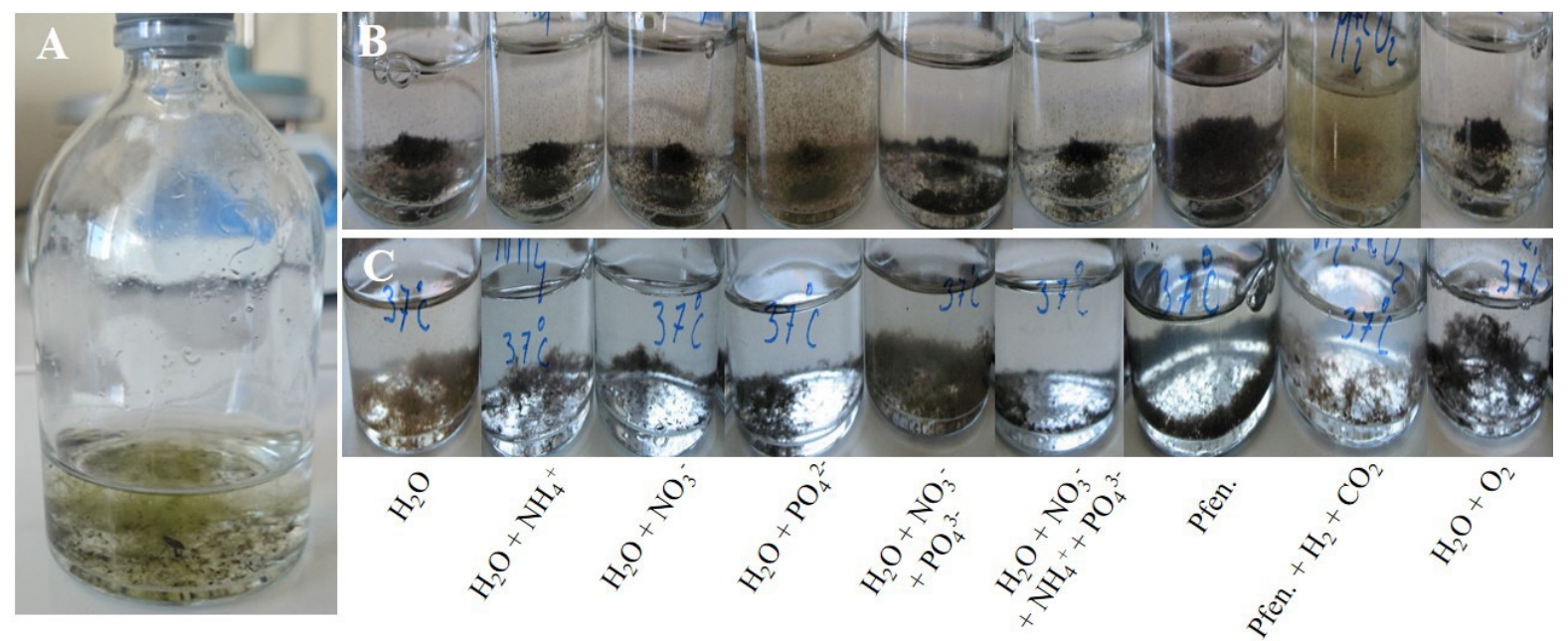
$37^{\circ} \mathrm{C}$.

Fig.1. The visual state of the experimental cultures. A - initial state ( 0 days). B - after 90 days at $24^{\circ} \mathrm{C}$. C - after 90 days at 

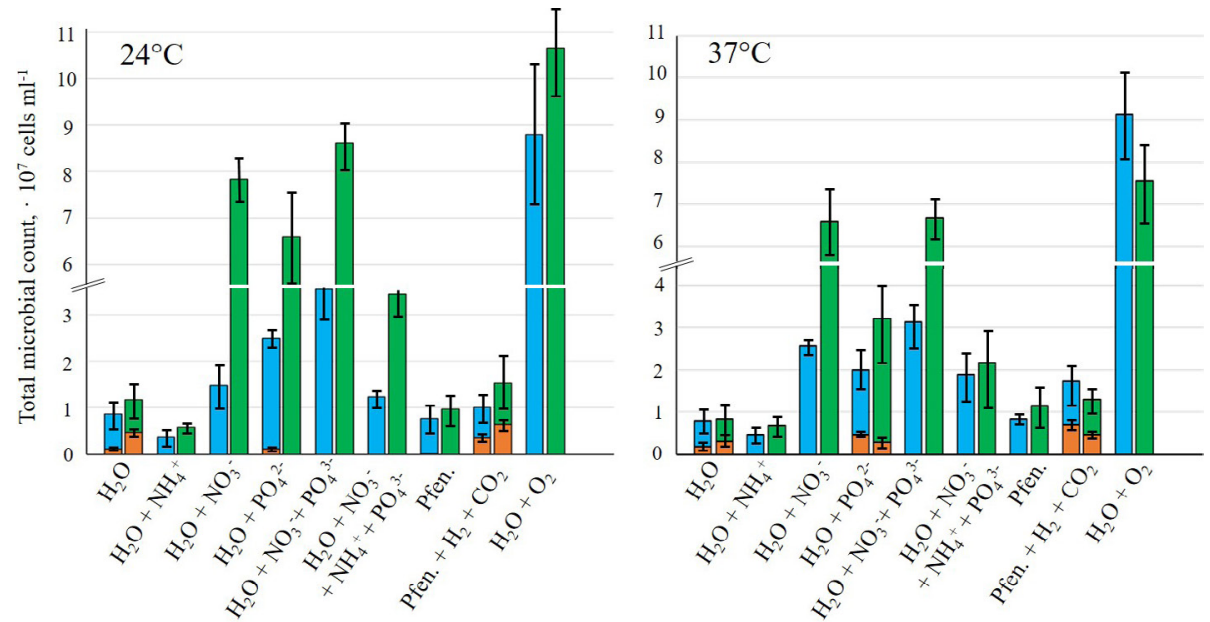

Fig.2. Total microbial count in enrichment cultures on the $30^{\text {th }}$ (blue columns) and $90^{\text {th }}$ (green columns) days of cultivation as well as the number of archaea of the phylum Euryarchaeota based on the FISH data (orange columns).

close to hydrogenotrophic methanogens of the genera Methanobacterium and Methanosphaerula as well as to a wide range of uncultured archaea from swamps, bioreactors and lake sediments (Fig. 4).

\section{Discussion and conclusions}

The results of a comprehensive analysis indicated that the microbial communities from the coastal mats can decompose the Spirogyra spp. biomass with the generation of methane and thereby serve as a potential source of its emissions into the atmosphere. However, methane is probably not the main end product of anaerobic destruction.

The cultivation revealed that the studied sample of the Spirogyra spp. biomass, as well as the coastal mats of filamentous algae from lakes Michigan and Mendota (Olapade et al., 2006; Zulkifly et al., 2012), contained anaerobic microorganisms. Since the analysed community contains methanogenic archaea that are sensitive to the presence of oxygen and are incapable of forming dormant forms (Liu and Whitman, 2008), we can assume the presence of stable hypoxia zones inside mats and below them, which corresponds to the data on the oxygen concentration in the interstitial waters of Baikal beaches covered with the Spirogyra spp. accumulations (Tomberg et al., 2017).

There was the process of methane generation during the destruction of biomass in the absence of additionally introduced nutrients and with the elevated concentrations of phosphates, whereas the introduction of additional nitrogen sources suppressed methanogenic activity (Fig. 3). Phosphates do not act as electron acceptors in the main types of anaerobic respiration and, therefore, do not directly affect the competition for reduced fermentation products between different groups of anaerobes. At the same time, a high concentration of phosphates in the medium (more than $20 \mathrm{mM}$ ) can suppress acetogenesis and thereby inhibit methane generation from acetate (Conrad et al., 2000). However, in case of the Spirogyra spp. destruction, the absence of a negative impact of the elevated $\mathrm{PO}_{4}^{3-}$ concentrations can be because obligate hydrogenotrophic species represented all detected methanogenic archaea. Differences in the number of methanogenic archaea and the amount of $\mathrm{CH}_{4}$ generated at different cultivation temperatures can result from greater competition from other groups of anaerobic microorganisms, whose numbers were significantly higher at $24^{\circ} \mathrm{C}$ (Fig. 2), as well as from
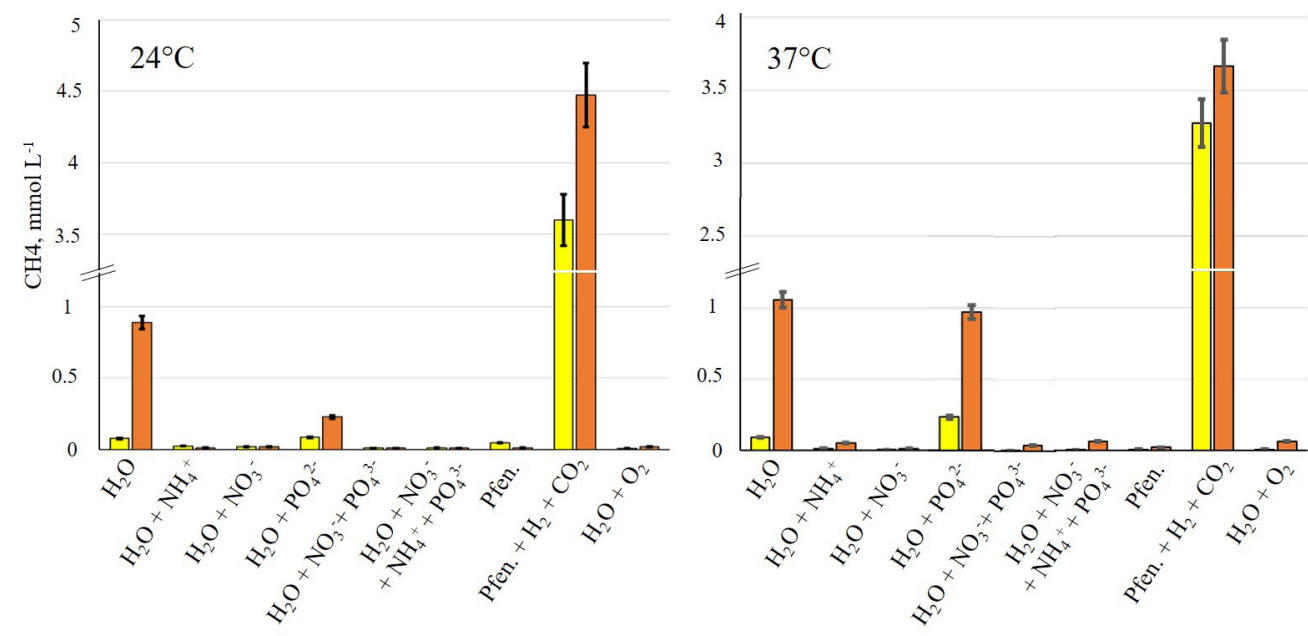

Fig.3. Methane concentrations in enrichment cultures on the $30^{\text {th }}$ (yellow columns) and $90^{\text {th }}$ (orange columns) days of cultivation. 


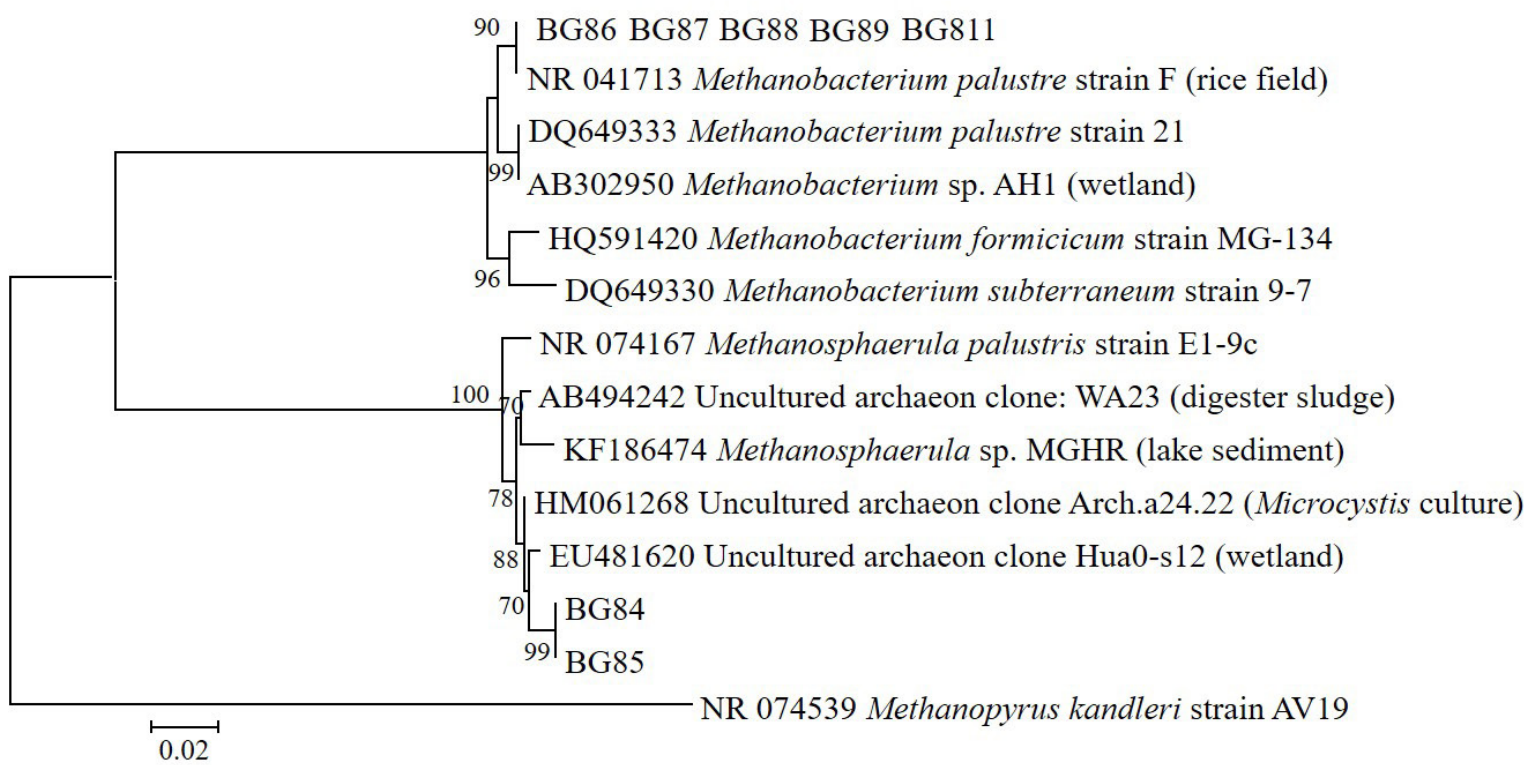

Fig.4. Phylogenetic tree of 16 rRNA sequences of metagenomic archaea detected in enrichment cultures with the Spirogyra biomass without additional salts.

heterogeneity in the composition of microorganisms introduced with biomass.

The reduction of $\mathrm{NO}_{3}{ }^{-}$is thermodynamically more beneficial than the reduction of $\mathrm{CO}_{2}$ to methane, due to which increased content of nitrates in the environment stimulates the development of nitratereducing microorganisms and leads to the suppression of the methane generation (Liu and Whitman, 2008). At the same time, the causes of inhibition of methane generation under conditions of increased ammonium concentration are not obvious. At high concentrations, uncharged ammonium molecules passively penetrate the cell membrane, leading to $\mathrm{pH}$ destabilization and inhibition of intracellular enzymes. The loss of intracellular $\mathrm{NH}_{3}$ by diffusion through the cytoplasmic membrane after previous permease-dependent consumption in the form of $\mathrm{NH}_{4}{ }^{+}$can lead to a decrease in proton motive force (Chen et al., 2008). However, $\mathrm{NH}_{4}{ }^{+}$is the main nitrogen source for most groups of methanogenic archaea (DeMoll, 1993), and the example of the communities from methane tanks and bioreactors has indicated that ammonium can have a negative impact on methanogenesis only at concentrations above $0.6 \mathrm{~g} \mathrm{~L}^{-1}$ (Yenigün and Demirel, 2013; Chen et al., 2016; Fischer et al., 2019). In the Pfennig's medium cultures $\left(\mathrm{NH}_{4} \mathrm{Cl}-0.33 \mathrm{~g} \mathrm{~L}^{-1}\right)$, a key influence on the number and activity of methanogenic microorganisms is rather the availability of methanogenesis substrates than the increased concentration of $\mathrm{NH}_{4}{ }^{+}$. In this regard, we can assume that the addition of ammonium salts either affected the initial stages of biomass destruction or provided an advantage for microorganisms with another type of anaerobic respiration under a limited amount of such substrates as $\mathrm{H}_{2} / \mathrm{CO}_{2}$.

During the cultivation, with the destruction of algal biomass, the largest amount of methane generated was $0.005-0.006 \mathrm{~m}^{3} \mathrm{CH}_{4} \mathrm{~kg}^{-1} \mathrm{DW}$, which is much lower than during the methanogenic decomposition of biomass of macro- and microalgae using biogas fermenters (Montingelli et al., 2015; Ramaraj et al., 2015; Milledge et al., 2019). For example, during the production of biogas from Spirogyra ellipsospora, the yield is $0.43 \mathrm{~m}^{3} \mathrm{CH}_{4} \mathrm{~kg}^{-1}$ DW (Ramaraj et al., 2015), whereas the biomass fermentation of other species of marine and freshwater macroalgae yields on average $0.20 \mathrm{~m}^{3} \mathrm{CH}_{4} \mathrm{~kg}^{-1}$ VS (VS - volatile solid) at VS $\approx 75$ $80 \%$ of DW (Montingelli et al., 2015; Milledge et al., 2019). The use of microalgae as a substrate ensures $0.02-0.60 \mathrm{~m}^{3} \mathrm{CH}_{4} \mathrm{~kg}^{-1} \mathrm{VS}$ depending on the species and conditions of anaerobic digestion (Mussgnug et al., 2010; Montingelli et al., 2015; Milledge et al., 2019). Of course, the technological process of the biogas production involves careful selection and control of physicochemical conditions of the environment as well as optimal organic loading rates, whose observance would increase the amount of methane produced from Spirogyra spp. by the investigated microbial community. Moreover, the closest homologues of the detected methanogenic archaea of the genera Methanobacterium and Methanosphaerula are mesophilic inhabitants of swamps, which indicates their adaptability to a high content of organic substrates in the environment. Nevertheless, the low diversity of methanogenic archaea, sensitivity to increased concentrations of nitrates and ammonium and relatively low productivity of methane generation even at mesophilic temperatures suggests that methane is not the main end product of organic matter destruction in coastal mats of Spirogyra spp. in Lake Baikal.

\section{Acknowledgements}

The fieldworks were carried out within the framework of the LIN SB RAS State Task No. 003452019-0009 (AAAA-A16-116122110067-8); molecular biological and microbiological studies were supported by the RFBR grant OFI-M No. 17-29-05040. 


\section{References}

Ask J., Karlsson J., Persson L. et al. 2009. Whole-lake estimates of carbon flux through algae and bacteria in benthic and pelagic habitats of clear-water lakes. Ecology 90: 19231932. DOI: 10.1890/07-1855.1

Auer M.T., Tomlinson L.M., Higgins S.N. et al. 2010. Great Lakes Cladophora in the 21st century: same algae different ecosystem. Journal of Great Lakes Research 36: 248-255. DOI: 10.1016/j.jglr.2010.03.001

Bolshakov A.M., Egorov A.V. 1987. Using the method of phase equilibrium degassing in gasometric studies in water areas. Okeanologiya [Oceanology] 37: 861-862. (in Russian)

Burggraf S., Mayer T., Amann S. et al. 1994. Identifying members of the domain Archaea with rRNA-targeted oligonucleotide probes. Applied and Environmental Microbiology 60: 3112-3119. DOI: 10.1128/ aem.60.9.3112-3119.1994

Byappanahalli M.N., Nevers M.B., Przybyla-Kelly K. et al. 2019. Great Lakes Cladophora harbors phylogenetically diverse nitrogen-fixing microorganisms. Environmental DNA 1: 186-195. DOI: $10.1002 /$ edn3.20

Chen Y., Cheng J.J., Creamer K.S. 2008. Inhibition of anaerobic digestion process: a review. Bioresource Technology 99: 4044-4064. DOI: 10.1016/j.biortech.2007.01.057

Chen X., Liu Y., Peng L. et al. 2016. Model-based feasibility assessment of membrane biofilm reactor to achieve simultaneous ammonium, dissolved methane, and sulfide removal from anaerobic digestion liquor. Scientific Reports 6. DOI: $10.1038 /$ srep25114

Chun C.L., Peller J.R., Shively D. et al. 2017. Virulence and biodegradation potential of dynamic microbial communities associated with decaying Cladophora in Great Lakes. Science of the Total Environment 574: 872-880. DOI: $10.1016 / \mathrm{j}$. scitotenv.2016.09.107

Conrad R., Klose M., Claus P. 2000. Phosphate inhibits acetotrophic methanogenesis on rice roots. Applied and Environmental Microbiology 66: 828-831. DOI: 10.1128/ aem.66.2.828-831.2000

DeMoll E. 1993. Nitrogen and phosphorus metabolism of methanogens. New York: Chapman \& Hall.

Depew D.C., Houben A.J., Guildford S.J. et al. 2011. Distribution of nuisance Cladophora in the lower Great Lakes: patterns with land use, near shore water quality and dreissenid abundance. Journal of Great Lakes Research 37: 656-671. DOI: 10.1016/j.jglr.2011.08.011

Fischer M.A., Güllert S., Refai S. et al. 2018. Longterm investigation of microbial community composition and transcription patterns in a biogas plant undergoing ammonia crisis. Microbial Biotechnology 12: 305-323. DOI: 10.1111/1751-7915.13313

Glöckner F.O., Fuchs B.M., Amann R. 1999. Bacterioplankton compositions of lakes and oceans: a first comparison based on fluorescence in situ hybridization. Applied and Environmental Microbiology 65: 3721-3726. DOI: 10.1128/aem.65.8.3721-3726.1999

Gubelit Y.I., Vainshtein M.B. 2011. Growth of enterobacteria on algal mats in the eastern part of the Gulf of Finland. Inland Water Biology 4: 132-136. DOI: 10.1134/ s1995082911020246

Hale S.S, Cicchetti G., Deacutis C.F. 2016. Eutrophication and hypoxia diminish ecosystem functions of benthic communities in a New England estuary. Frontiers in Marine Science 3. DOI: 10.3389/fmars.2016.00249

Hecky R.E., Hesslein R.H. 1995. Contributions of benthic algae to lake food webs as revealed by stable isotope analysis. Journal of the North American Benthological Society 14: 631-653. DOI: $10.2307 / 1467546$

Huisman J., Codd G.A., Paerl H.W. et al. 2018.
Cyanobacterial blooms. Nature Reviews Microbiology 16: 471-483. DOI: 10.1038/s41579-018-0040-1

Jenny J.-P., Normandeau A., Francus P. et al. 2016. Urban point sources of nutrients were the leading cause for the historical spread of hypoxia across European lakes. Proceedings of the National Academy of Sciences 113: 1265512660. DOI: $10.1073 /$ pnas. 1605480113

Kravtsova L.S., Izhboldina L.A., Khanaev I.V. et al. 2012. Disturbances of the vertical zoning of green algae in the coastal part of the Listvennichnyi gulf of Lake Baikal. Doklady Biological Sciences 447: 350-352. DOI: 10.1134/ s0012496612060026

Kravtsova L.S., Izhboldina L.A., Khanaev I.V. et al. 2014. Nearshore benthic blooms of filamentous green algae in Lake Baikal. Journal of Great Lakes Research 40: 441-448. DOI: 10.1016/j.jglr.2014.02.019

Kravtsova L.S., Mizandrontsev I.B., Vorobyova S.S. et al. 2020. Influence of water motion on the spatial distribution of Spirogyra in Lake Baikal. Journal of Great Lakes Research 46: 29-40. DOI: 10.1016/j.jglr.2019.09.004

Kumar S., Stecher G., Tamura K. 2016. MEGA7: Molecular Evolutionary Genetics Analysis version 7.0 for bigger datasets. Molecular Biology and Evolution 33: 18701874. DOI: $10.1093 / \mathrm{molbev} / \mathrm{msw} 054$

Kuznetsov S.I., Dubinina G.A. 1989. Metody izucheniya vodnykh mikroorganizmov [Methods for Investigation of Aquatic Microorganisms]. Moscow: Nauka.

Liang X., Zhang X., Sun Q. et al. 2015. The role of filamentous algae Spirogyra spp. in methane production and emissions in streams. Aquatic Sciences 78: 227-239. DOI: 10.1007/s00027-015-0419-2

Liu Y., Whitman W.B. 2008. Metabolic, phylogenetic and ecological diversity of the methanogenic Archaea. Annals of the New York Academy of Sciences 1125: 171-189. DOI: 10.1196/annals.1419.019

Matveev V., aRobson B.J. 2014. Aquatic food web structure and the flow of carbon. Freshwater Reviews 7: 1-24. DOI: $10.1608 /$ frj-7.1.720

Mikhailov I.S., Zakharova Y.R., Bukin Y.S. et al. 2019. Co-occurrence networks among Bacteria and microbial eukaryotes of Lake Baikal during a spring phytoplankton bloom. Microbial Ecology 77: 96-109. DOI: 10.1007/ s00248-018-1212-2

Milledge J., Nielsen B., Maneein S. et al. 2019. A brief review of anaerobic digestion of algae for bioenergy. Energies 12. DOI: $10.3390 /$ en 12061166

Montingelli M.E., Tedesco S., Olabi A.G. 2015. Biogas production from algal biomass: a review. Renewable and Sustainable Energy Reviews 43: 961-972. DOI: 10.1016/j. rser.2014.11.052

Morrison J.M., Murphy C.L., Baker K. et al. 2017. Microbial communities mediating algal detritus turnover under anaerobic conditions. PeerJ 5. DOI: 10.7717/peerj.2803

Mussgnug J.H., Klassen V., Schlüter, A. et al. 2010. Microalgae as substrates for fermentative biogas production in a combined biorefinery concept. Journal of Biotechnology 150: 51-56. DOI: 10.1016/j.jbiotec.2010.07.030

Olapade O.A., Depas M.M., Jensen E.T. et al. 2006. Microbial communities and fecal indicator bacteria associated with Cladophora mats on beach sites along Lake Michigan shores. Applied and Environmental Microbiology 72: 19321938. DOI: 10.1128/aem.72.3.1932-1938.2006

Potemkina T.G., Potemkin V.L., Kotsar O.V. et al. 2018 Climate factors as a possible trigger of modern ecological changes in shallow zone of Lake Baikal (Russia). International Journal of Environmental Studies 75: 86-98. DOI: $10.1080 / 00207233.2017 .1406727$

Ramaraj R., Unpaprom Y., Whangchai N. et al. 2015. Culture of macroalgae Spirogyra ellipsospora for long-term 
experiments, stock maintenance and biogas production. Emergent Life Science Research 1: 38-45.

Sambrook J., Fritsch E.F., Maniatis T. 1989. Molecular cloning: a laboratory manual. New York: Cold Spring Harbor.

Schneider S.C., Cara M., Eriksen T.E. et al. 2014. Eutrophication impacts littoral biota in Lake Ohrid while water phosphorus concentrations are low. Limnologica 44: 90-97. DOI: 10.1016/j.limno.2013.09.002

Schwarz J.I.K., Eckert W., Conrad R. 2008. Response of the methanogenic microbial community of a profundal lake sediment (Lake Kinneret, Israel) to algal deposition. Limnology and Oceanography 53: 113-121. DOI: 10.4319/ lo.2008.53.1.0113

Smith V.H., Joye S.B., Howarth R.W. et al. 2006. Eutrophication of freshwater and marine ecosystems. Limnology and Oceanography 51: 351-355. DOI: 10.4319/ lo.2006.51.1_part_2.0351

Timoshkin O.A., Bondarenko N.A., Volkova E.A. et al. 2015. Mass development of green filamentous algae of the genera Spirogyra and Stigeoclonium (Chlorophyta) in the littoral zone of the Southern Part of Lake Baikal. Hydrobiological Journal 51: 13-23. DOI: 10.1615/hydrobj.v51.i1.20

Timoshkin O.A., Samsonov D.P., Yamamuro M. et al. 2016. Rapid ecological change in the coastal zone of Lake Baikal (East Siberia): is the site of the world's greatest freshwater biodiversity in danger? Journal of Great Lakes Research 42(3): 487-497. DOI: 10.1016/j.jglr.2016.02.011

Timoshkin O.A., Moore M.V., Kulikova N.N. 2018. Groundwater contamination by sewage causes benthic algal outbreaks in the littoral zone of Lake Baikal (East Siberia).
Journal of Great Lakes Research 44: 230-244. DOI: 10.1016/j. jglr.2018.01.008

Tomberg I.V., Sakirko M.V. Molozhnikova E.V. et al. 2017. Ecological characteristics of the splash zone of Lake Baikal (by chemical components). In: Fundamental Problems of the Ecology of Russia, p. 193. (in Russian)

Volkova E.A., Bondarenko N.A., Timoshkin O.A. 2018. Morphotaxonomy, distribution and abundance of Spirogyra (Zygnematophyceae, Charophyta) in Lake Baikal, East Siberia. Phycologia 57: 298-308. DOI: 10.2216/17-69.1

Wallner G., Amann R., Beisker W. 1993. Optimizing fluorescent in situ hybridization with rRNA-targeted oligonucleotide probes for flow cytometric identification of microorganisms. Cytometry 14: 136-143. DOI: 10.1002/ cyto. 990140205

West W.E., Coloso J.J., Jones S.E. 2012. Effects of algal and terrestrial carbon on methane production rates and methanogen community structure in a temperate lake sediment. Freshwater Biology 57: 949-955. DOI: 10.1111/j.1365-2427.2012.02755.x

Wetzel R.G. 1995. Death, detritus, and energy flow in aquatic ecosystems. Freshwater Biology 33: 83-89. DOI: 10.1111/j.1365-2427.1995.tb00388.x

Yenigün O., Demirel B. 2013. Ammonia inhibition in anaerobic digestion: a review. Process Biochemistry 48: 901-911. DOI: 10.1016/j.procbio.2013.04.012

Zulkifly S., Hanshew A., Young E.B. et al. 2012. The epiphytic microbiota of the globally widespread macroalga Cladophora glomerata (Chlorophyta, Cladophorales). American Journal of Botany 99: 1541-1552. DOI: 10.3732/ajb.1200161 